\title{
Effect of inserted spacer in hepatic cell-penetrating multifunctional peptide component on the DNA intracellular delivery of quaternary complexes based on modular design
}

\author{
This article was published in the following Dove Press journal: \\ International Journal of Nanomedicine \\ 24 November 2016 \\ Number of times this article has been viewed
}

\section{Luchen Zhang' \\ Zhenbo $\mathrm{Li}^{\prime}$ \\ Fangli Sun ${ }^{2}$ \\ Yuhong $\mathrm{Xu}^{\prime}$ \\ Zixiu Du'}

'School of Pharmacy, Shanghai Jiao Tong University, Shanghai, ${ }^{2}$ School of Engineering, Zhejiang Agriculture and Forestry University, Lin'an, Zhejiang Province, People's Republic of China

Correspondence: Zixiu Du School of Pharmacy, Shanghai Jiao

Tong University, 800 Dongchuan Road, Shanghai 200240, People's Republic of

China

Tel +86 2I 34204739

Fax +86 2I 34204457

Email zixiudu@sjtu.edu.cn

\begin{abstract}
A safe and efficient quaternary gene delivery system (named Q-complexes) was constructed based on self-assembly of molecules through noncovalent bonds. This system was formulated through the cooperation and competing interactions of cationic liposomes, multifunctional peptides, and DNA, followed by coating hyaluronic acid on the surface of the ternary complexes. The multifunctional peptide was composed of two functional domains: penetrating hepatic tumor-targeted cell moiety (KRPTMRFRYTWNPMK) and a wrapping gene sequence (polyarginine 16). The effect of spacer insertion between the two domains of multifunctional peptide on the intracellular transfection of Q-complexes was further studied. Experimental results showed that the formulations assembled with various peptides in the spacer elements possessed different intercellular pathways and transfection efficiencies. The Q-complexes containing peptide in the absence of spacer element $\left(\mathrm{P}_{\mathrm{a}}\right)$ showed the highest gene expression among all samples. The Q-complexes containing peptides with a noncleavable spacer $G A\left(\mathrm{P}_{\mathrm{c}}\right)$ had no ability of intracellular nucleic acid delivery, whereas those with a cleavable spacer $R V R R\left(\mathrm{P}_{\mathrm{d}}\right)$ showed moderate transfection activity. These results demonstrated that the different spacers inserted in the multifunctional peptide played an important role in in vitro DNA transfection efficiency. Atomic force microscopy images showed that the morphologies of ternary complexes ( $\left.\mathrm{LP}_{\mathrm{c}} \mathrm{D}\right)$ and Q-complexes $\left(\mathrm{HL}_{\mathrm{c}} \mathrm{PD}\right)$ were crystal lamellas, whereas those of other nanocomplexes were spheres. Circular dichroism showed the changed configuration of peptide with spacer $G A$ in nanocomplexes compared with that of its free state, whereas the $\mathrm{P}_{\mathrm{a}}$ configuration without spacer in nanocomplexes was consistent with that of its free state. The present study contributed to the structural understanding of Q-complexes, and further effective modification is in progress.
\end{abstract}

Keywords: Q-complexes, spacer elements, multifunctional peptides, lipid component, intracellular transfection

\section{Introduction}

Gene delivery can increase or decrease the expression of any protein in a cell theoretically, ${ }^{1}$ and thus drugs based on gene have been regarded a promising treatment for many serious diseases, such as cancer and genetic disorders. ${ }^{2,3}$ Effective gene delivery to the target sites remains a challenge because of the difficulty of transporting these negatively charged macromolecules to overcome various physical barriers without degradation. ${ }^{1,4}$ A safe and efficient delivery system is thus needed for a successful gene therapy. ${ }^{1,4,5}$ Since 1960 s, nonviral vectors based on cationic polymers ${ }^{6-9}$ and lipids ${ }^{10}$ 
have been preferred as the carriers to wrap and transport genes. ${ }^{11}$ Numerous efforts have been made to optimize the designing strategies of nonviral vectors to overcome the barriers during delivery process..$^{5}$ The conventional method of designing targeted drug carriers is via chemical conjugation of functional moieties; ${ }^{12}$ the conjugation of various ligands requires chemical reactions and may destroy the conformation of biomolecules, thereby resulting in inactivation and cytotoxicity. The self-assembly of molecules via noncovalent bonds to form an organized structure is most helpful in drug delivery system, maintains the nature of each component, and enhances the delivery activity of carriers through the synergies of all functional moieties.

On the basis of self-assembly of molecules via noncovalent bonds, we rationally constructed a highly effective and biologically responsive delivery system (Q-complexes) using nontoxic lipids (1,2-dioleoyl-3-trimethylammonium-propane [DOTAP] and 1,2-dioleoylsn-glycero-3-phosphatidylethanolamine [DOPE]), peptide, and hyaluronic acid (HA). Briefly, the formulation is first composed of a cationic liposome, multifunctional peptide, and DNA at optimized ratios, which can finally self-assemble into ternary complexes (LPD). The ternary complex was associated with negatively charged HA and formulated quaternary complexes (HLPD, also named as Q-complexes). Specifically, we applied a hepatic tumorspecific cell-penetrating peptide (KRPTMRFRYTWNPMK) $)^{13}$ to polyarginine $16\left(\mathrm{R}_{16}\right)$ in the absence or presence of spacer to create a multifunctional peptide, which could specifically permeate hepatic tumor cells and tightly condense nucleic acids. The HA coated at the surface of ternary complexes is in charge of shielding the negative charge of the nanoparticle surface, as well as the oriented binding to the tumor tissues and cells because HA actively targets receptors (such as CD44) distributed on the surfaces of the tumor cells. ${ }^{14,15}$ From the similar reported formulation, ${ }^{16}$ we could conclude that some of KRPTMRFRYTWNPMK in the multifunctional peptide protruded at the surface of LPD, which possibly induces the nanoparticles to penetrate into the tumor cells, and the lipid component destroys the endosomal membranes through membrane fusion function of DOPE. ${ }^{17}$

In the present study, we found that the transfection efficiency of HLPD is closely related to the inserted spacer of the multifunctional peptides, between KRPTMRFRYTWNPMK and $R_{16}$. Thus, we investigated the effect of spacer element on the in vitro DNA transfection of HLPD and mainly explored the characteristics and internalization mechanism of HLPD containing the peptides with different spacers between KRPTMRFRYTWNPMK and $\mathrm{R}_{16}$. The cell uptake and gene expression of Q-complexes after incubation with different inhibitors were analyzed to validate the successful intracellular gene delivery pathway. In this text, $\mathrm{H}$ represents HA, L represents cationic liposome that was composed of DOTAP/DOPE at the weight ratio of $1: 1$, P represents peptide, and $D$ represents DNA. For example, HLP D refers to HA, cationic liposome, $\mathrm{P}_{\mathrm{a}}$, and DNA at the weight ratio of 14:1:4:1.

\section{Materials and methods Materials}

DOTAP and DOPE were purchased from Sigma-Aldrich Co. (St Louis, MO, USA). The peptide sequence $\mathrm{R}_{16} \mathrm{KMP}-$ NWTYRFRMTPRK $\left(\mathrm{P}_{\mathrm{a}}\right), \mathrm{R}_{16}\left(\mathrm{P}_{\mathrm{b}}\right)$, and peptide with the spacers $G A$ and $R V R R$ based on $\mathrm{P}_{\mathrm{a}}$ (named as $\mathrm{P}_{\mathrm{c}}$ and $\mathrm{P}_{\mathrm{d}}$ ) were purchased from China Peptides (Shanghai, People's Republic of China) and dissolved in $10 \mathrm{mg} / \mathrm{mL}$ of nuclease-free water (Thermo Fisher Scientific, Waltham, MA, USA). The plasmid pCI-Luc comprising the luciferase gene of pGL3 was purchased from Invitrogen. The plasmids were amplified in DH5 $\alpha$ strain of Escherichia coli and prepared using a GoldHi EndoFree Plasmid Maxi Kit (CWBiotech, Beijing, People's Republic of China). HA ( $\mathrm{Mw}=34 \mathrm{kDa}$ ) was purchased from Shandong Freda Biotechnology Co., Ltd. (Shandong, People's Republic of China). In addition, fluorescein isothiocyanatelabeled HA (FITC-HA) was synthesized as reported. ${ }^{18}$

\section{Preparation of cationic liposome}

Liposome preparation was described previously. ${ }^{19}$ Briefly, the required amounts of DOTAP and DOPE were first dissolved in chloroform at the weight ratio of $1: 1$, and a thin lipid film was produced via slowly evaporating the chloroform overnight with a rotary evaporator under vacuum conditions. The lipid film was subsequently hydrated with double-distilled water at room temperature to produce a crude suspension of $1 \mathrm{mg} / \mathrm{mL}$. The crude suspension was sonicated for $10 \mathrm{~min}$ to obtain the final product.

\section{Formation of LPD and HLPD}

Ternary complexes (LPD) were prepared by mixing the cationic liposome with different peptides and DNA solution at the weight ratio of $1: 4: 1$ (ie, charge ratio of $0.3: 4.4: 1$ for $\mathrm{P}_{\mathrm{a}}, \mathrm{P}_{\mathrm{c}}$, and $\mathrm{P}_{\mathrm{d}}$ and charge ratio of 0.3:8.4:1 for $\mathrm{P}_{\mathrm{b}}$ ). These complexes were incubated for $30 \mathrm{~min}$ to formulate LPD at room temperature. The thoroughly mixed suspensions were mixed with HA solution at a precise ratio of 14:1 HA/DNA (ie, 5.9:1 charge ratio) and maintained for $15 \mathrm{~min}$ to produce Q-complexes (HLPD). For physicochemical studies of HLPD, the complexes were prepared and diluted with 
double-distilled water. For in vitro transfection, Opti-MEM was used as diluent.

\section{Hydrodynamic size and zeta potential measurements}

The hydrodynamic size and zeta potential of LPD and HLPD complexes were measured via dynamic light scattering using a Zetasizer Nano ZS (Malvern Instruments, Malvern, UK) at $25^{\circ} \mathrm{C} \pm 0.1{ }^{\circ} \mathrm{C}$. The amount of DNA used in each formulation was $2 \mu \mathrm{g}$. The values for each formulation are the mean values of three measurements.

\section{Gel electrophoresis assay}

Approximately $1 \mu \mathrm{g}$ of DNA and $10 \mu \mathrm{L}$ of complex suspensions were used in the gel electrophoresis assay. All samples, except for $1 \mathrm{~kb}$ DNA ladder (Foregene, Chengdu, People's Republic of China), were added to $2 \mu \mathrm{L}$ of $6 \times$ loading buffer (Thermo Fisher Scientific) before loading the samples onto a $1 \% \mathrm{w} / \mathrm{v}$ agarose gel in Tris-acetate-EDTA buffer, which contained $3 \mu \mathrm{L}$ of GelRed. The samples were electrophoresed at $90 \mathrm{~V}$ for $30 \mathrm{~min}$ and visualized under ultraviolet (UV) light.

\section{Atomic force microscope}

A drop of LPD and HLPD nanocomplexes was applied onto the mica. After a few seconds, the drop was dried through blotting with the filter paper. The total component concentration of each sample was $0.3 \mathrm{mg} / \mathrm{mL}$. The morphology of LPD and HLPD was examined using an atomic force microscope (Nanoscope IIIa; Digital Instruments/Veeco, Inc., Santa Barbara, CA, USA).

\section{Circular dichroism}

Circular dichroism measurements were performed with aqueous preparations of LPD and HLPD complexes, as well as peptide and HA components at the same concentrations similar to those for the LPD and HLPD complexes. The individual components were used as controls to determine their native structures. All spectra were obtained in a JASCO $\mathrm{J}-815$ spectropolarimeter using a $0.1 \mathrm{~cm}$ rectangular quartz cuvette cell, at a scan rate of $50 \mathrm{~nm} / \mathrm{min}$, data pitch of $1 \mathrm{~nm}$, response time of $1 \mathrm{~s}$, and bandwidth of $1 \mathrm{~nm}$.

\section{Cell culture}

SMMC-7721 (human hepatoma) cells were obtained from Shanghai Institutes for Biological Sciences, Chinese Academy of Sciences (Shanghai, People's Republic of China). Cell culture media and reagents were purchased from Thermo Fisher Scientific. SMMC-7721 cells were cultured in RPMI-1640 medium. The medium used for cell culture was supplemented with $10 \% \mathrm{v} / \mathrm{v}$ fetal bovine serum and $1 \% \mathrm{v} / \mathrm{v}$ penicillin/streptomycin solution. All cell lines were incubated at $37^{\circ} \mathrm{C}$ in a humidified atmosphere with $5 \% \mathrm{CO}_{2}$.

\section{Flow cytometry and confocal laser scanning microscopy}

Dil-dyed lipid component was used to monitor the trafficking of nanocomplexes. The cell uptake of the complexes was quantitatively measured via flow cytometry (FACS Calibur; $\mathrm{BD}$, Worcestershire, NJ, USA). Cells were seeded in 24-well plates at the density of $1 \times 10^{5}$ cells per well and incubated at $37^{\circ} \mathrm{C}$ in a humidified atmosphere with $5 \% \mathrm{CO}_{2}$ for $24 \mathrm{~h}$ before transfection. The culture medium was subsequently removed, and the cells were rinsed with $500 \mu \mathrm{L}$ of $1 \times$ phosphate buffered saline (PBS). Afterward, the complexes containing $2 \mu \mathrm{g}$ of pGL3 plasmid in $500 \mu \mathrm{L}$ of Opti-MEM were added to each well. The cells were incubated at $37^{\circ} \mathrm{C}$ with $5 \% \mathrm{CO}_{2}$ for $4 \mathrm{~h}$, after which the complex suspensions were removed. The cells were collected and prepared for flow cytometry assay. For confocal microscopy, fluorescent-labeled Q-complex formulations were prepared with DOTAP and DOPE at 1:1 weight ratio containing DiI at $1.0 \%$ weight ratio of total lipids. In this experiment, the cells were incubated for $4 \mathrm{~h}$. The cells were mixed with $4 \%$ paraformaldehyde, permeabilized with $0.3 \%$ triton in PBS for $10 \mathrm{~min}$, and incubated for $5 \mathrm{~min}$ at room temperature with DAPI $(0.2 \mathrm{mg} / \mathrm{mL}$; Sigma-Aldrich). The cells were washed with PBS and sealed in mounting media (Invitrogen). Subsequently, visualization was carried out on a Leica TCS SP8 laser scanning microscope system (Leica Microsystems, Wetzlar, Germany).

\section{Expression of green fluorescent protein (GFP) reporter gene}

SMMC-7721 cells were seeded in 24-well plates at the density of $1 \times 10^{5}$ cells per well and incubated at $37^{\circ} \mathrm{C}$ in a humidified atmosphere with $5 \% \mathrm{CO}_{2}$ for $24 \mathrm{~h}$ before transfection. The cells were first rinsed with $500 \mu \mathrm{L}$ of $1 \times \mathrm{PBS}$, and the complexes containing $1 \mu \mathrm{g}$ of GFP plasmid in $500 \mu \mathrm{L}$ of Opti-MEM were added to each well. The cells were incubated at $37^{\circ} \mathrm{C}$ with $5 \% \mathrm{CO}_{2}$ for $4 \mathrm{~h}$. The suspensions were subsequently replaced with fresh medium, and the cells were incubated for additional $20 \mathrm{~h}$. The cells were observed under a fluorescence microscope.

\section{Intracellular internalization mechanism assay of HLPD}

Cells were seeded in 96 -well plates at the density of $2 \times 10^{4}$ cells per well and incubated at $37^{\circ} \mathrm{C}$ in a humidified atmosphere with 
$5 \% \mathrm{CO}_{2}$ for $24 \mathrm{~h}$ prior to transfection. The culture medium was removed, and the cells were rinsed with $200 \mu \mathrm{L}$ of $1 \times$ PBS. The complexes containing $250 \mathrm{ng}$ of pGL3 in $200 \mu \mathrm{L}$ of Opti-MEM were added to each well. The cells were incubated at $37^{\circ} \mathrm{C}$ with $5 \% \mathrm{CO}_{2}$ for $4 \mathrm{~h}$. Afterward, the complex suspensions were replaced with fresh complete culture medium, and the cells were incubated under the same condition for a further $20 \mathrm{~h}$. Cells were then lysed with Reporter Lysis Buffer (Promega, Southampton, UK). A Luciferase Assay System (Promega) was used to measure luciferase activity with an illuminometer (Berthold Technologies, Bad Wildbad, Germany). The amount of protein in each lysate was determined with a Micro BCA Protein Assay Kit (Thermo Scientific) using a microplate reader (Bio-Rad Laboratories Inc., Hercules, CA, USA). Luciferase activity was expressed as relative light units per milligram of protein (RLU/mg protein). Moreover, four endocytic inhibitors, namely, dynamin inhibitor (DI: dynasore; Sigma-Aldrich), CD44-antibody (Abcam, Cambridge, MA, USA), chlorpromazine (CPZ, Aladdin, People's Republic of China), and 5( $N$-ethyl- $N$-isopropyl) amiloride (EIPA) were used to impede the dynamin-dependent, CD44-mediated, and macropinocytosis pathways. Cells were pretreated with endocytic inhibitors before transfection. For dynamin inhibition, the cells were first rinsed with $1 \times \mathrm{PBS}$, and the cells were subsequently incubated for $1 \mathrm{~h}$ at $37^{\circ} \mathrm{C}$ with $80 \mu \mathrm{M}$ dynasore, $0.2 \%$ DMSO only, or the culture medium alone. Similarly, cells were incubated with anti-CD44 antibody (rabbit monoclonal [EPR1013Y] to CD44; 1/250), CPZ (20 $\mu \mathrm{M}, 1 \mathrm{~h}$ incubation), and EIPA (100 $\mu \mathrm{M}$, $30 \mathrm{~min}$ incubation) with $0.1 \% \mathrm{DMSO}$ at $37^{\circ} \mathrm{C}$. After inhibitor pretreatment, the complexes were added to transfect cells. A luciferase activity assay was then conducted with the same procedures as mentioned earlier. For flow cytometric analysis, cells were incubated for $4 \mathrm{~h}$ in the presence or absence of endocytosis inhibitors of dynasore or CD44 antibody. Cell uptake was measured via flow cytometry (FACS Calibur).

\section{Statistical analysis}

All experiments were performed in triplicate, and the data are represented as mean $\pm \mathrm{SD}$. Student's $t$-tests were used for statistical analysis among groups. A value of $* P<0.05$ was considered significant. All the analyses were conducted using GraphPad Prism 5 Instat software (GraphPad, San Diego, CA, USA).

\section{Results}

\section{Physicochemical characteristics of ternary and Q-complexes}

The amino acid sequences of multifunctional peptides are shown in Table 1. These sequences were used as the peptide
Table I Multifunctional peptides prepared via human neoplasm lineage-homing cell-penetrating peptide (KRPTMRFRYTWNPMK) conjugated with polyarginine 16 with or without different spacers

\begin{tabular}{ll}
\hline Peptide & Amino acid sequences \\
\hline $\mathrm{P}_{\mathrm{a}}$ & RRRRRRRRRRRRRRRRKMPNWTYRFRMTPRK \\
$\mathrm{P}_{\mathrm{b}}$ & RRRRRRRRRRRRRRRR \\
$\mathrm{P}_{\mathrm{c}}$ & RRRRRRRRRRRRRRRRGAKMPNWTYRFRMTPRK \\
$\mathrm{P}_{\mathrm{d}}$ & RRRRRRRRRRRRRRRRRVRRKMPNWTYRFRMTPRK \\
\hline
\end{tabular}

Note: $P_{a}-P_{d}$ refers to the different peptide used.

component for investigation of the effect of spacer in peptide on the characteristics and delivery efficiency of Q-complexes. The hydrodynamic size and zeta potential of the LPD and HLPD complexes studied are illustrated in Figure 1. The complexes except for LP D were basically $\sim 100 \mathrm{~nm}$ in diameter with appropriate positive charge for LPD in the range of $20-50 \mathrm{mV}$. For HLPD, the values were reversed to negative charge ranging from $-30 \mathrm{mV}$ to $-40 \mathrm{mV}$ of zeta potential. The zeta potential of HLP $\mathrm{D}$ was $-19 \mathrm{mV}$ at the weight ratio of $1: 4: 1$. Therefore, we further investigated the formulation of Q-complexes based on $\mathrm{P}_{\mathrm{c}}$. The small selfassembled structure of ternary complexes was obtained at $8: 1$ weight ratio of $\mathrm{P}_{\mathrm{c}}: \mathrm{D}$, and the size and zeta potential of LPD and HLPD were found to be similar (Figure S1) at 4:1 weight ratio of $\mathrm{P}_{c}: \mathrm{D}$. The gel electrophoresis results indicated that all complexes, except the samples based on $\mathrm{P}_{\mathrm{c}}$, were able to condense nucleic acids effectively at their optimized formulations (Figures 2 and S2), whereas LP $\mathrm{D}_{\mathrm{c}}$ and HLP $\mathrm{D}$ showed poor DNA condensation ability. The atomic force microscope images (Figure 3 ) showed that $\mathrm{LP}_{\mathrm{a}} \mathrm{D}$ and HLP $\mathrm{D}$ presented uniform spheres. The ternary and Q-complexes containing $\mathrm{P}_{\mathrm{b}}$ and $\mathrm{P}_{\mathrm{d}}$ also formed spherical nanoparticles with various sizes. However, LP D and HLP D formed crystal lamellas, which were considerably different from those of other samples.

\section{Circular dichroism spectra}

To investigate the alteration in the conformation of peptides in the complexes, the circular dichroism of Q-complexes (HLP $\mathrm{a}_{\mathrm{a}}$, HLP $\mathrm{D}$, and $\left.\mathrm{HLP}_{\mathrm{d}} \mathrm{D}\right)$ was examined in the range of 190-300 nm (Figure 4). Responsive ternary complexes $\left(\mathrm{LP} \mathrm{D}_{\mathrm{a}}, \mathrm{LP}_{\mathrm{c}} \mathrm{D}\right.$, and $\left.\mathrm{LP}_{\mathrm{d}} \mathrm{D}\right)$, peptides $\left(\mathrm{P}_{\mathrm{a}}, \mathrm{P}_{\mathrm{c}}\right.$, and $\left.\mathrm{P}_{\mathrm{d}}\right)$, and free HA were also examined. The circular dichroism signal of free liposome was not measured because of the absence of chromophores absorbing in the UV region. ${ }^{17}$ As shown in Figure 4A, the magnitude of negative circular dichroism band had a $\lambda_{\max }$ at $\sim 208 \mathrm{~nm}$ in individual $\mathrm{P}_{\mathrm{a}}$ and $\mathrm{LP}_{\mathrm{a}} \mathrm{D}$. The $\lambda_{\max }$ of free HA was located at $210 \mathrm{~nm}$, and the peak of HLP $\mathrm{D}$ was the overlap of $\mathrm{P}_{\mathrm{a}}$ and HA component peaks. The abovementioned results demonstrated that $\mathrm{P}_{\mathrm{a}}$ showed 

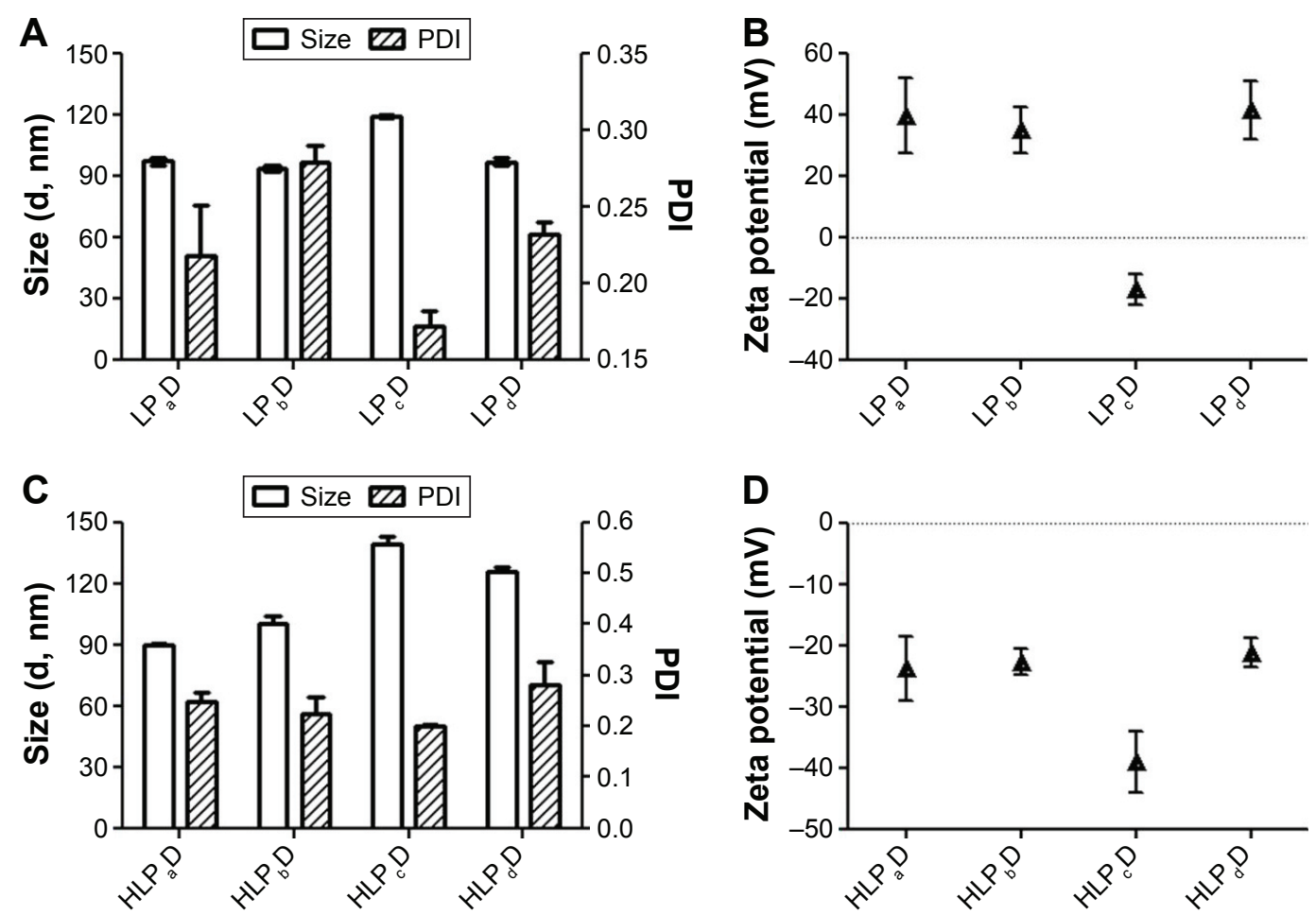

Figure I Results of hydrodynamic sizes and zeta potential measurements of ternary complexes (LPD) and Q-complexes (HLPD) wrapping pGL3 plasmid. Notes: (A) The sizes and size distributions of $L P_{a} D, L P_{b} D, L P_{c} D$, and $L P_{d} D$; (B) zeta potential of $L P_{a} D, L P_{b} D, L P_{c} D$, and $L P_{f} D$; (C) the sizes and size distributions of $H L P_{a} D$, $H L P_{b} D, H L P D$, and HLP D; and (D) zeta potential of HLPD, HLP $P_{b} D, H L P P_{c}$, and HLP D. LPD: a cationic liposome, multifunctional peptide, and DNA at optimized ratios; HLPD: $H$ represents hyaluronic acid, $L$ represents cationic liposome that was composed of DOTAP/DOPE at a $I: I$ weight ratio, $P$ represents peptide $\left(P_{a}-P_{d}\right.$ refers to the different peptide used), and $\mathrm{D}$ represents DNA.

Abbreviations: DOTAP, I,2-dioleoyl-3-trimethylammonium-propane; DOPE, I,2-dioleoylsn-glycero-3-phosphatidyl-ethanolamine; PDI, polydispersity index.

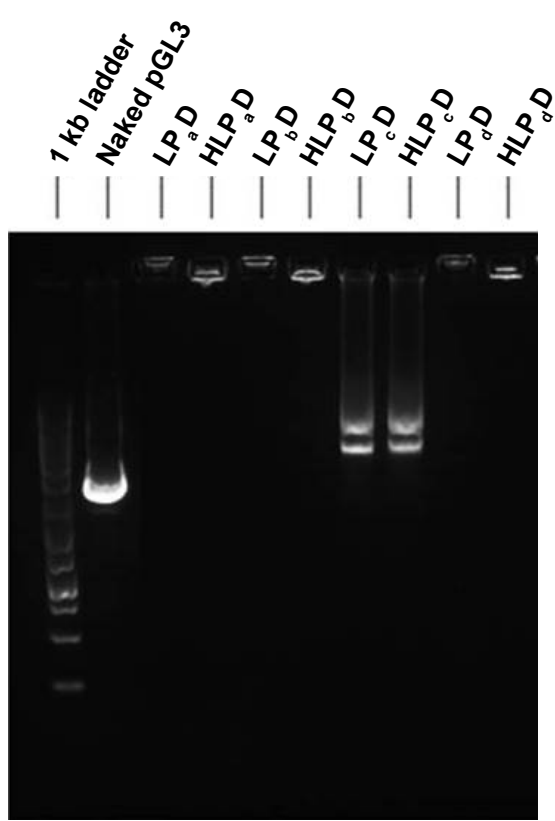

Figure 2 Electrophoretic mobility in 1\% agarose gel for LPD and HLPD wrapping pGL3 plasmid: I kb ladder, naked pGL3, LP ${ }_{a} D, H_{2} D, P_{a} D, H_{b} P_{b} D, L_{c} D, H_{c} D$, $L P P_{d} D$, and HLP D.

Notes: LPD: a cationic liposome, multifunctional peptide, and DNA at optimized ratios; HLPD: $H$ represents hyaluronic acid, $L$ represents cationic liposome that was composed of DOTAP/DOPE at a I:I weight ratio, $\mathrm{P}$ represents peptide $\left(\mathrm{P}_{\mathrm{a}}-\mathrm{P}_{\mathrm{d}}\right.$ refers to the different peptide used), and $D$ represents DNA.

Abbreviations: DOTAP, I,2-dioleoyl-3-trimethylammonium-propane; DOPE, I,2dioleoylsn-glycero-3-phosphatidyl-ethanolamine. an unchanged $\alpha$-helix configuration in a free state, which was the same as in $\mathrm{LP}_{\mathrm{a}} \mathrm{D}$ and $\mathrm{HLP}_{\mathrm{a}} \mathrm{D}$. Furthermore, the $\lambda_{\max }$ at $\sim 208 \mathrm{~nm}$ appeared in free $\mathrm{P}_{\mathrm{c}}$, but moved to $210 \mathrm{~nm}$ in $\mathrm{LP}_{\mathrm{c}} \mathrm{D}$ and $\mathrm{HLP}_{\mathrm{c}} \mathrm{D}$, and also appeared in a positive peak at $\sim 195 \mathrm{~nm}$ in $\mathrm{LP}_{\mathrm{c}} \mathrm{D}$ and $\mathrm{HLP}_{\mathrm{c}} \mathrm{D}$. The result indicated that the secondary structure of $\mathrm{P}_{\mathrm{c}}$ had changed from $\alpha$-helix toward $\beta$-sheet (Figure 4B). The negative $\lambda_{\max }$ of peptide in $\mathrm{LP}_{\mathrm{d}} \mathrm{D}$ and free $\mathrm{P}_{\mathrm{d}}$ at $200 \mathrm{~nm}$ indicated the random coil, and the $\lambda_{\text {max }}$ of peptide in $\mathrm{HLP}_{\mathrm{d}} \mathrm{D}$ was at $218 \mathrm{~nm}$ (Figure 4C), which showed that the secondary structure of $\mathrm{P}_{\mathrm{d}}$ in $\mathrm{HLP}_{\mathrm{d}} \mathrm{D}$ was the transition state from random coil into $\beta$-sheet.

\section{Cell uptake}

The Q-complexes containing $\mathrm{P}_{\mathrm{a}}, \mathrm{P}_{\mathrm{b}}$, and $\mathrm{P}_{\mathrm{d}}$, respectively, were effectively internalized after $4 \mathrm{~h}$ of transfection (Figure 5). The equivalent mean fluorescence intensity of the cells after incubation with Q-complexes and the corresponding ternary complexes could be observed from the cell uptake transfected to SMMC-7721 cells. Such observation indicated that the internalization efficiency of nucleic acids did not drop after coating the surface of ternary complexes with HA. However, the Q-complexes containing $\mathrm{P}_{\mathrm{c}}$ were not easily endocytosed by the tumor cells. 
A

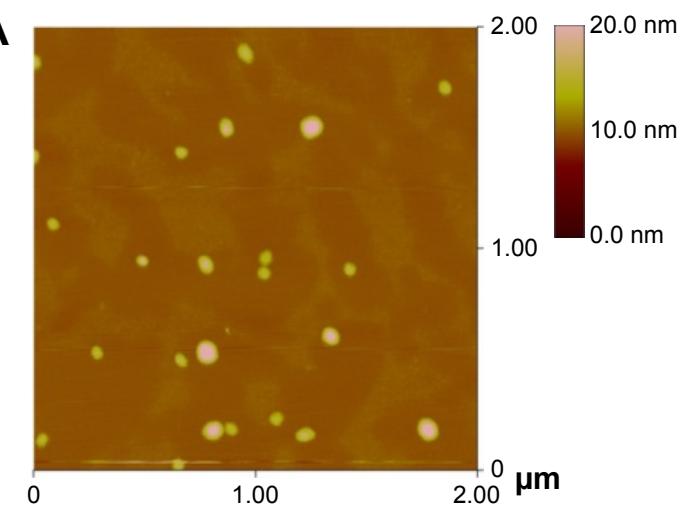

C

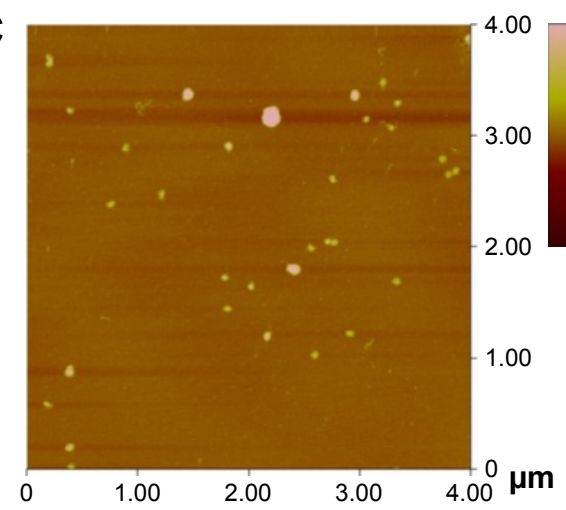

E

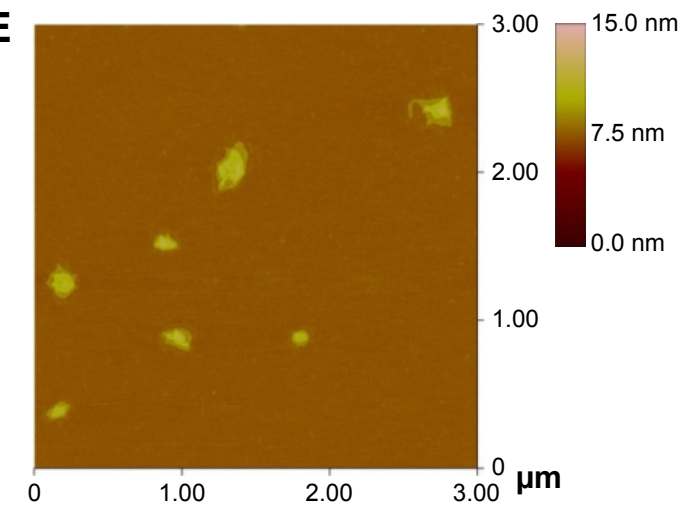

G

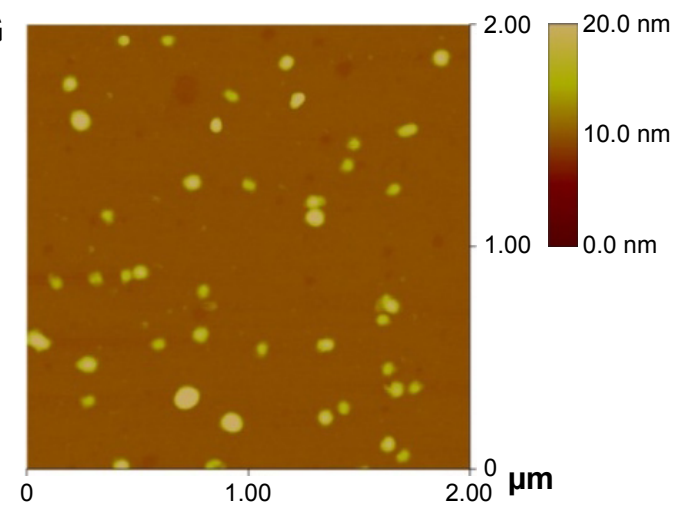

B

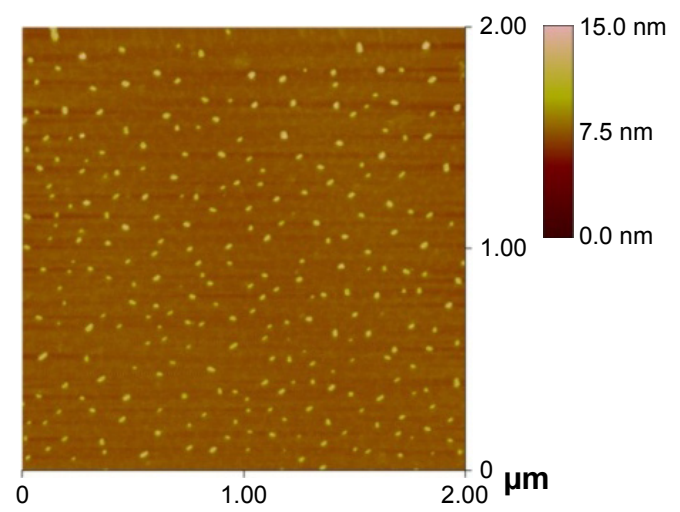

D

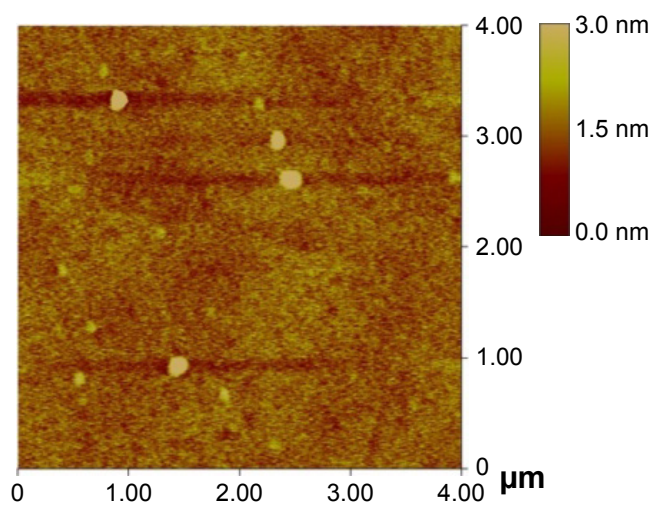

$F$
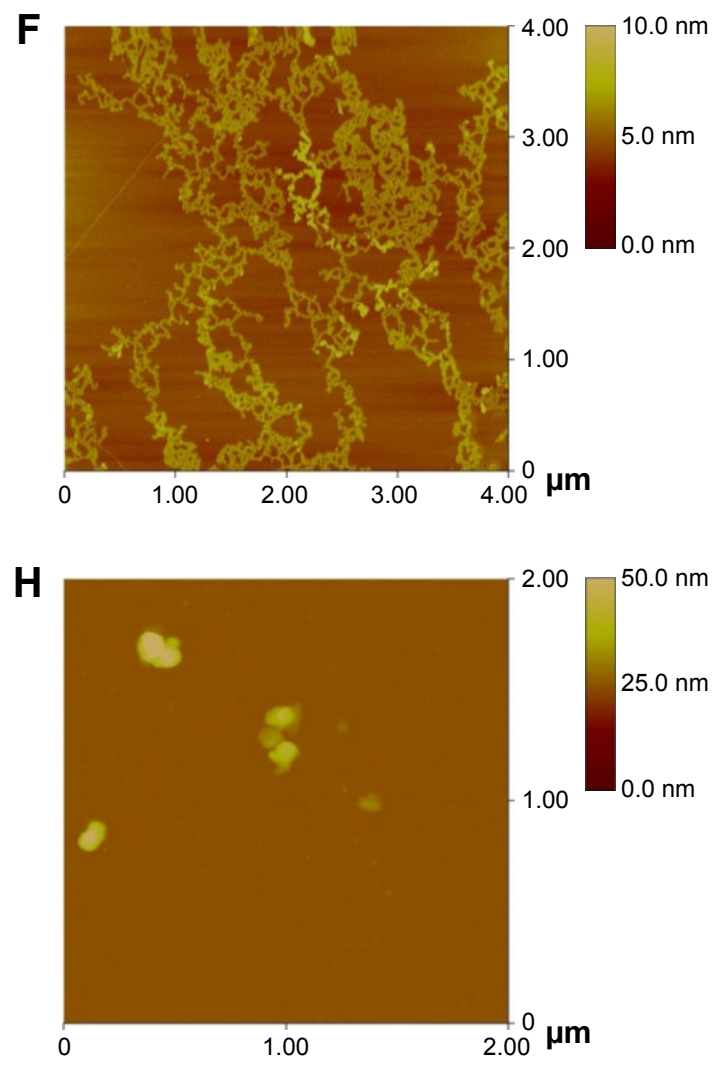

Figure 3 Morphologies of LPD and HLPD wrapping PGL3 plasmid observed via an atomic force microscope.

Notes: (A) LP D; (B) HLP D; (C) LP D; (D) HLP D; (E) LP D; (F) HLP D; (G) LP D; and (H) HLP D. LPD: a cationic liposome, multifunctional peptide, and DNA at optimized ratios; HLPD: $H$ represents hyaluronic acid, $L$ represents cationic liposome that was composed of DOTAP/DOPE at a I:I weight ratio, $P$ represents peptide $\left(P_{a}-P_{d}\right.$ refers to the different peptide used), and $\mathrm{D}$ represents DNA.

Abbreviations: DOTAP, I,2-dioleoyl-3-trimethylammonium-propane; DOPE, I,2-dioleoylsn-glycero-3-phosphatidyl-ethanolamine. 
A

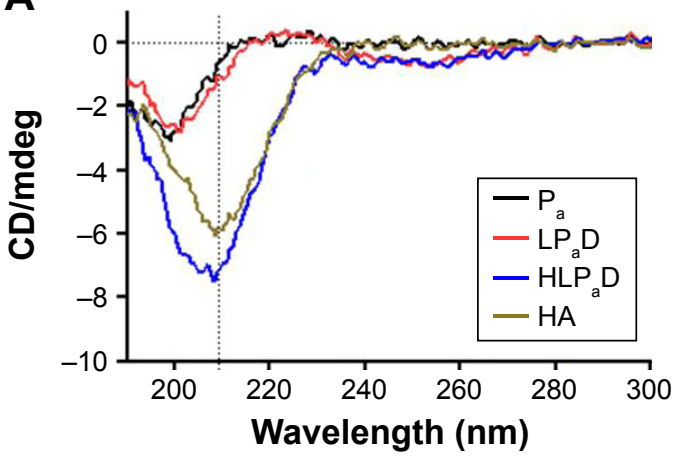

B

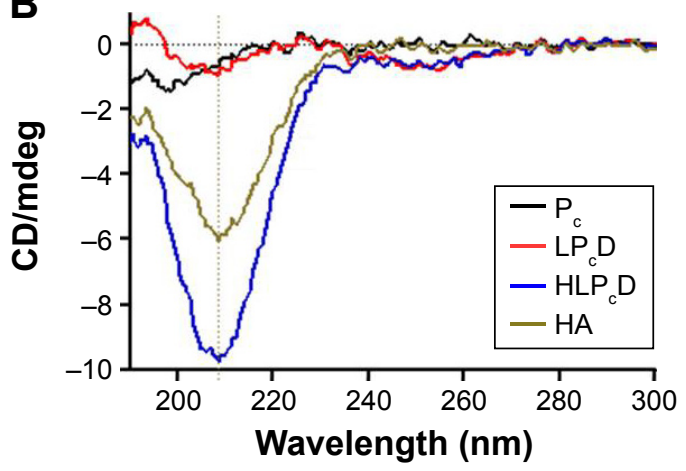

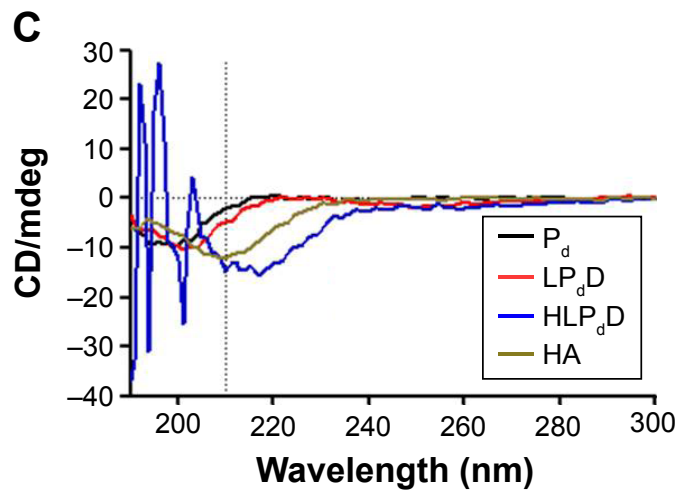

Figure $4 \mathrm{CD}$ spectra of individual peptide, ternary complexes, Q-complexes, and individual hyaluronic acid (HA).

Notes: (A) P, HA, LP D, and HLPD; (B) P, HA, LPD, and HLP D; and (C) P, HA, LP D, and HLP D. LPD: a cationic liposome, multifunctional peptide, and DNA at optimized ratios; HLPD: $H$ represents hyaluronic acid, $L$ represents cationic liposome that was composed of DOTAP/DOPE at a I:I weight ratio, $P$ represents peptide $\left(P_{a}-P_{d}\right.$ refers to the different peptide used), and D represents DNA.

Abbreviations: CD, circular dichroism; DOTAP, I,2-dioleoyl-3-trimethylammonium-propane; DOPE, I,2-dioleoylsn-glycero-3-phosphatidyl-ethanolamine.

\section{EGFP expression}

Fluorescence microscope was used to observe the GFP expression in varying intensities after incubation with SMMC-7721 cells for $24 \mathrm{~h}$. The HLP D sample showed the highest transfection activity (Figure 6) in all the samples

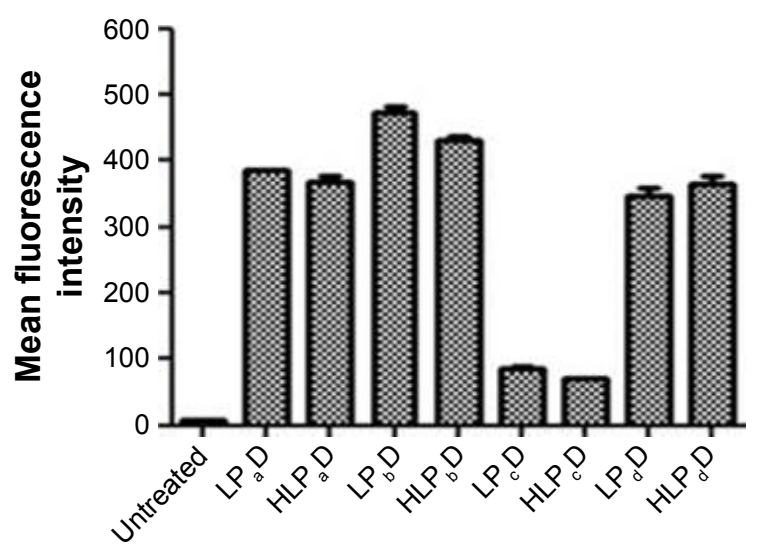

Figure 5 Cellular uptake of LPD (LPD, LP ${ }_{b} D, L P D$, and LP ${ }_{d}$ ) and HLPD (HLP D, $H_{L} P_{b} D, H L P{ }_{c} D$, and $H L P_{d} D$ ) binding $P G L 3$ plasmid (using $1 \%$ Dil in a liposome component as the fluorescent tracer).

Notes: LPD: a cationic liposome, multifunctional peptide, and DNA at optimized ratios; HLPD: $H$ represents hyaluronic acid, $L$ represents cationic liposome that was composed of DOTAP/DOPE at I:I weight ratio, $P$ represents peptide $(P-P$ refers to the different peptide used), and $D$ represents DNA.

Abbreviations: DOTAP, I,2-dioleoyl-3-trimethylammonium-propane; DOPE, I,2dioleoylsn-glycero-3-phosphatidyl-ethanolamine. containing $\mathrm{P}_{\mathrm{a}}-\mathrm{P}_{\mathrm{d}}$. Specifically, the GFP expression efficiency of complexes was in the order of samples containing the following peptides: $\mathrm{P}_{\mathrm{a}}>\mathrm{P}_{\mathrm{b}}>\mathrm{P}_{\mathrm{d}}>\mathrm{P}_{\mathrm{c}}$. The GFP expression results indirectly reflected the DNA delivery trend of Q-complexes with different multifunctional peptides.

\section{Luciferase transfection and internalization pathways of ternary and Q-complexes}

SMMC-7721 cells were transfected with LPD and HLPD complexes for the investigation of both transfection efficiency and internalization pathways of Q-complexes. Figure 7 illustrates that the intercellular activity of the ternary and Q-complexes containing $\mathrm{P}_{\mathrm{a}}$ showed the highest transfection efficiency among all the samples in the absence of inhibitors, and the complexes containing $\mathrm{P}_{\mathrm{b}}$ showed lower transfection activity compared with that of complexes containing $\mathrm{P}_{\mathrm{a}}$. On the contrary, the complexes containing $\mathrm{P}_{\mathrm{c}}$ barely delivered DNA into the cells. The samples containing $P_{d}$ showed higher DNA transfection efficiency than those complexes containing $\mathrm{P}_{c}$.

The unchangeable transfection efficiencies of all complexes could be observed after incubation with CD44 antibody (Figure 7A), which indicated the minimal contribution of CD44-mediated internalization to the intercellular transfection 


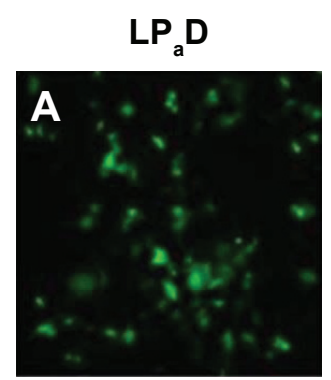

$\mathrm{LP}_{\mathrm{c}} \mathbf{D}$

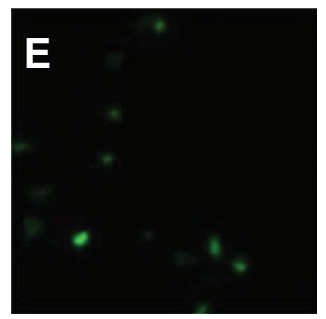

HLP ${ }_{a}$ D

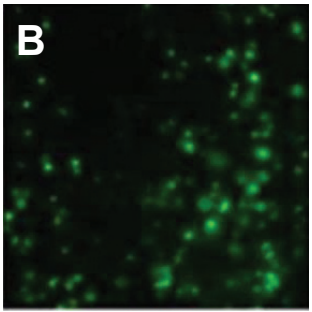

HLP ${ }_{c} D$

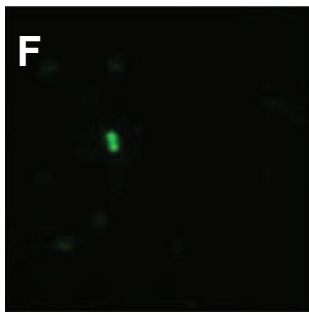

$\operatorname{LP}_{b} D$

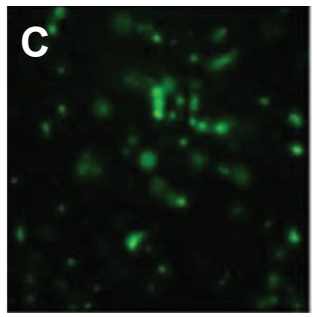

$L P_{d} \mathbf{D}$

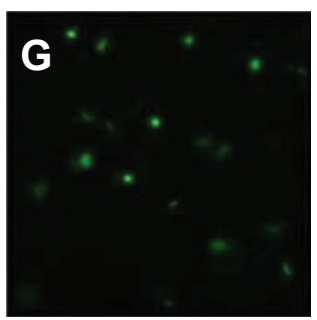

HLP ${ }_{b} D$

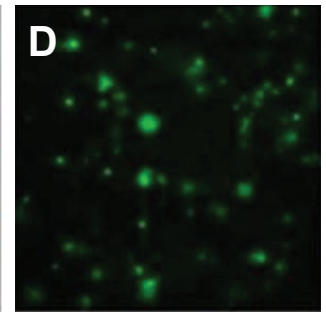

$H L P_{d} D$

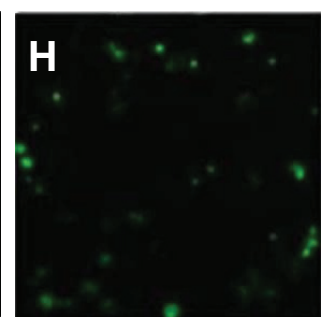

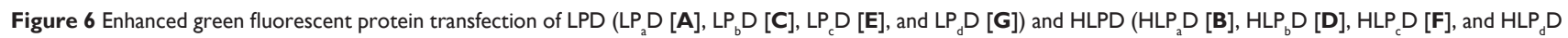
[H]) in SMMC-772I cells incubated for $24 \mathrm{~h}$.

Notes: LPD: a cationic liposome, multifunctional peptide, and DNA at optimized ratios; HLPD: H represents hyaluronic acid, L represents cationic liposome that was composed of DOTAP/DOPE at a I:I weight ratio, $P$ represents peptide $(P-P$ refers to the different peptide used), and $D$ represents $D N A$. Magnification $\times I 00$. Abbreviations: DOTAP, I,2-dioleoyl-3-trimethylammonium-propane; DOPE, I,2-dioleoylsn-glycero-3-phosphatidyl-ethanolamine.

A

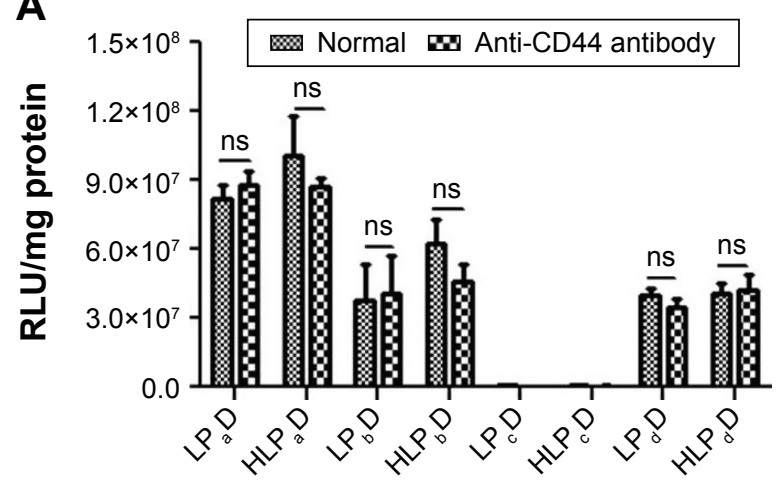

C

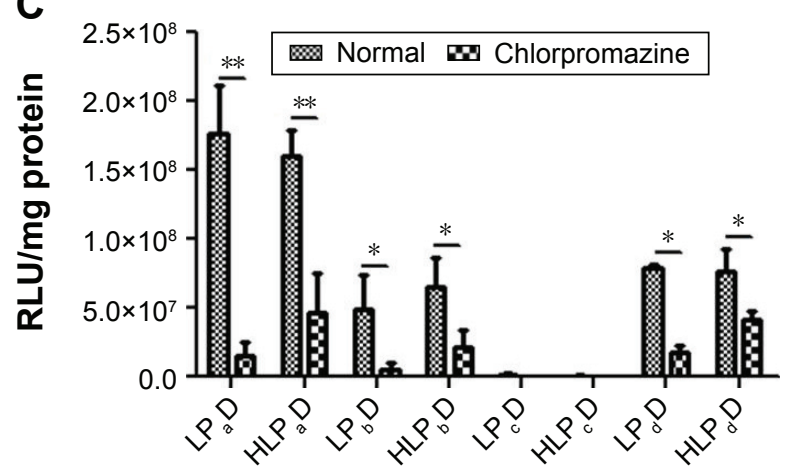

B

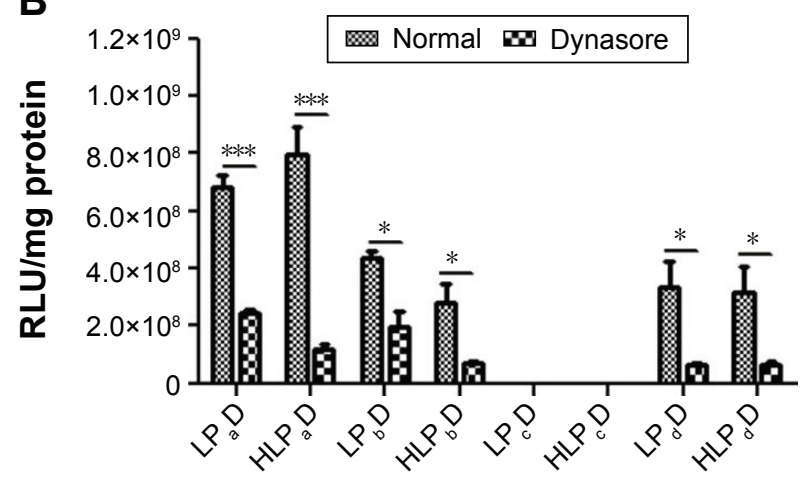

D

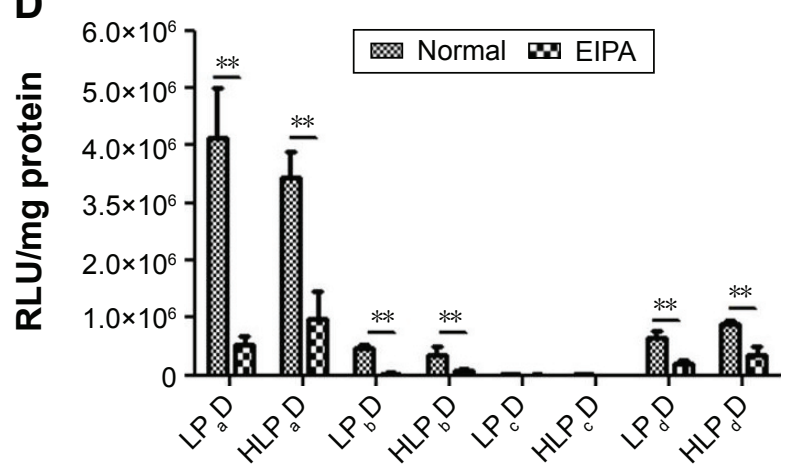

Figure 7 Luciferase transfection of LPD (LP ${ }_{a} D, L_{b} D, L_{c} D$, and $\left.L P_{d} D\right)$ and HLPD (HLP D, HLP D, HLP D, and HLP $\left.{ }_{d} D\right)$ in SMMC-772I cells incubated for 24 h. Notes: In the absence (normal group) and presence (dynasore group) of (A) anti-CD44 antibody ( $50 \mu \mathrm{g} / \mathrm{mL})$ pretreated for I h, (B) dynamin inhibitor I with $0.2 \%$ DMSO in the solution (DI; dynasore, $80 \mu \mathrm{M}$ ) pretreated for I h, (C) chlorpromazine (CPZ; $20 \mu \mathrm{M})$ pretreated for I h, and (D) 5-(N-ethyl-N-isopropyl) amiloride (EIPA; I00 $\mu$ M) with $0.1 \%$ DMSO in the solution pretreated for $30 \mathrm{~min}$. Values are the means of four replicates \pm SD. "** Represents an alpha value of $P<0.05$, “***" represents an alpha value of $P<0.01$, and “*****" represents an alpha value of $P<0.00$ I. LPD: a cationic liposome, multifunctional peptide, and DNA at optimized ratios; HLPD: $H$ represents hyaluronic acid, L represents cationic liposome that was composed of DOTAP/DOPE at a I:I weight ratio, $P$ represents peptide $\left(P_{a}-P_{d}\right.$ refers to the different peptide used), and $D$ represents DNA.

Abbreviations: RLU/mg protein, relative light units per milligram of protein; DOTAP, I,2-dioleoyl-3-trimethylammonium-propane; DOPE, I,2-dioleoylsn-glycero-3phosphatidyl-ethanolamine; ns, not significant. 

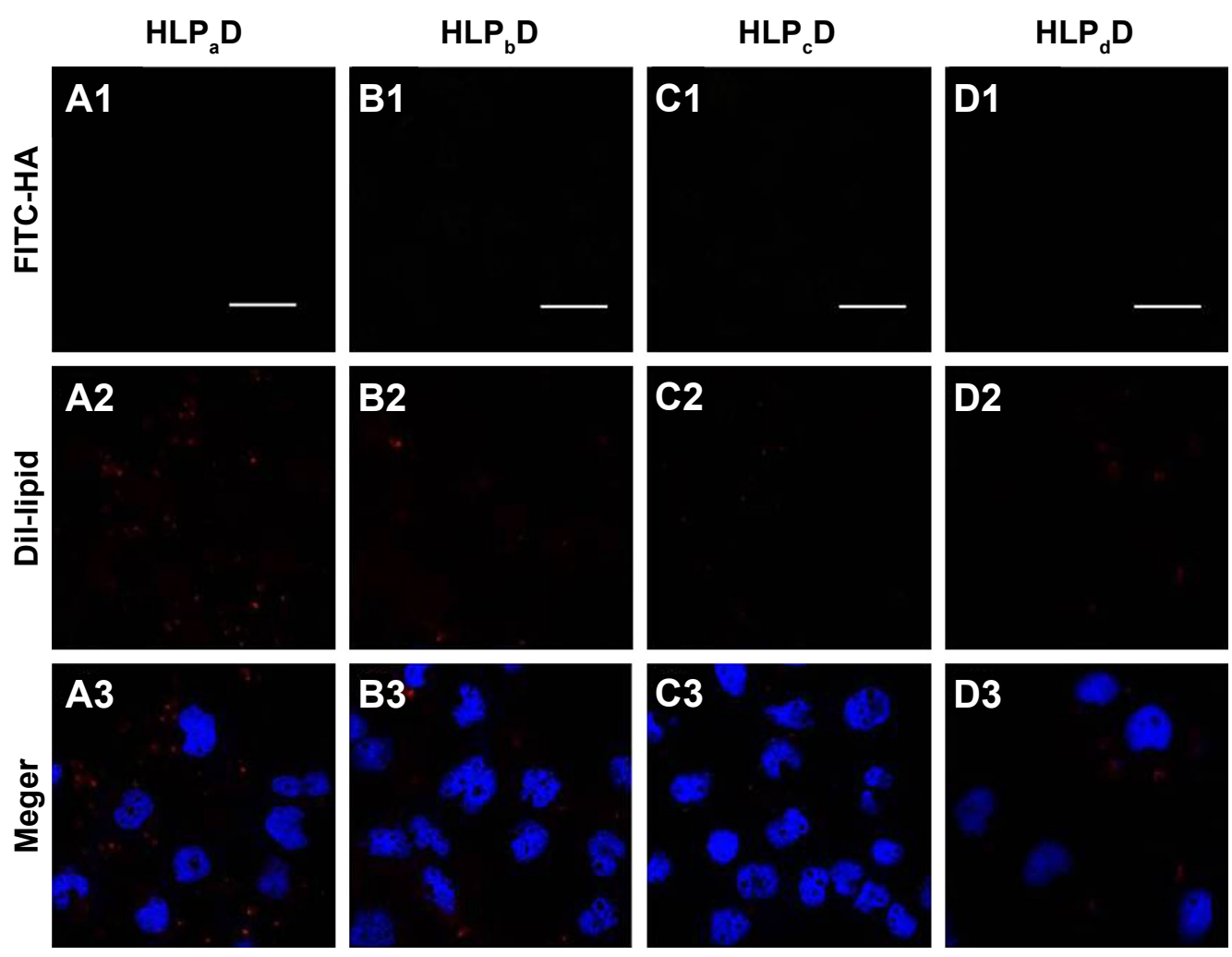

Figure 8 Confocal microscopic images of the intracellular localization of HLPD (HLPD, HLP D, HLP ${ }_{c}$, and HLP $\left.{ }_{d} D\right)$ identified using FITC-conjugated HA (green) and Dil-labeled lipid component (red). SMMC-772I cells were incubated for $4 \mathrm{~h}$ with Q-complexes, and the nuclei were dyed with DAPI (blue).

Notes: (AI-DI) indicated FITC-conjugated HA; panels (A2-D2) showed Dil-labelled lipid component; and (A3-D3) showed the merger of FITC, Dil and DAPI; LPD: a cationic liposome, multifunctional peptide, and DNA at optimized ratios; HLPD: $\mathrm{H}$ represents hyaluronic acid, $\mathrm{L}$ represents cationic liposome that was composed of DOTAP/ DOPE at a I:I weight ratio, $P$ represents peptide $\left(P_{a}-P_{d}\right.$ refers to the different peptide used), and $D$ represents DNA. Scale bar $=25 \mu m$ for all images.

Abbreviations: DOTAP, I,2-dioleoyl-3-trimethylammonium-propane; DOPE, I,2-dioleoylsn-glycero-3-phosphatidyl-ethanolamine.

activity of the complexes. In addition, a significant drop in the luciferase expression of the samples containing $\mathrm{P}_{\mathrm{a}}$ was observed after pretreatment with dynasore (Figure 7B). This result showed that the internalization pathway of these nanocomplexes was mainly dynamin-dependent, thereby reflecting a strong penetrating ability of the peptide component in the nanoparticles. ${ }^{13}$ The internalization mechanism of most LPD and HLPD was also partly both clathrin- ${ }^{20}$ (Figure 7C) and macropinocytosis-dependent ${ }^{21}$ (Figure 7D) pathways.

We further investigated the intracellular paths of Q-complexes observed through confocal microscopy (Figure 8). FITC-HA and DiI-labeled lipid component (red) were used to monitor the trafficking of HLPD inside SMMC-7721 cells. Nuclei were stained with DAPI (blue). After incubation for $4 \mathrm{~h}$, the $\operatorname{HLP}_{\mathrm{a}} \mathrm{D}$ and $\mathrm{HLP}_{\mathrm{b}} \mathrm{D}$ inside the SMMC-7721 cells were observed through DiI-labeled lipid component, but the dots of FITC-HA were not found. This result implied that HA component had separated from the remaining components of Q-complexes before termination of incubation. Similarly, it also indicated that the FITC-HA of Q-complexes could only be efficiently endocytosed through CD44-mediated pathway (Figure 9). We also found that
anti-CD44 antibody impeded the fluorescence intensity of FITC-HA, and dynasore could not prevent the cell uptake of FITC-HA. Therefore, HLP $\mathrm{D}$ could not be endocytosed by the SMMC-7721 cells.

\section{Discussion}

Multifunctional peptide consists of both nearly neutral (KRPTMRFRYTWNPMK) and cationic peptide $\left(\mathrm{R}_{16}\right)$ sequences. Thus, the effects of incorporating peptide between these two peptide sequences are important for rationally designing a delivery system. A large gap of transfection efficiency between $\mathrm{HLP}_{\mathrm{a}} \mathrm{D}$ and $\mathrm{HLP}_{\mathrm{c}} \mathrm{D}$ inspired us to investigate the role of the incorporating spacer in the peptide component of Q-complexes. We selected two representative peptide spacers (GA and $R V R R$ ) as different spacer elements based on the original peptide of $\mathrm{P}_{\mathrm{a}}$ (Table 1) and verified whether these changes would affect the formulation and transfection efficiency of Q-complexes. In addition, we inhibited the intercellular uptake pathways, mainly including the CD44 mediating and dynamin-dependent pathways that HA and the tumor cell-penetrating peptide (KMPNWTYRFRMTPRK) specifically depended on, ${ }^{13}$ respectively. Q-complexes 
A

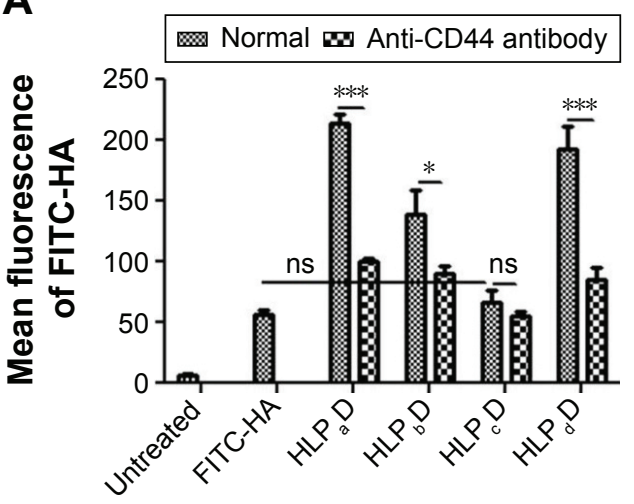

B

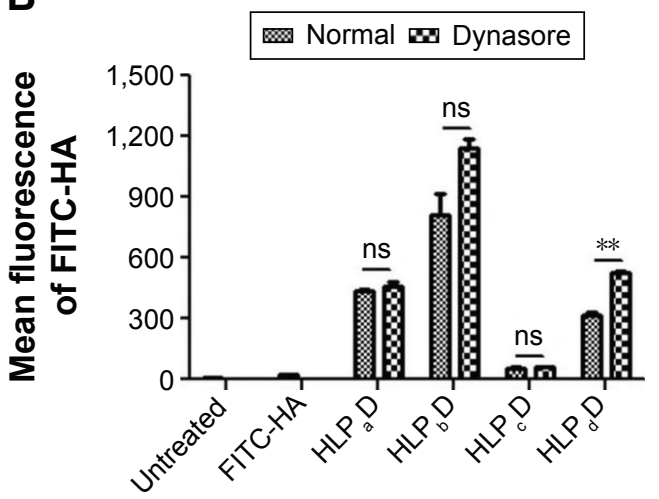

Figure 9 Dil intensity of HLPD (HLP $D, H_{a} P_{b} D, H L P D$, and HLP $\left.{ }_{d} D\right)$ in SMMC-772I cells incubated for 4 h in the absence (normal group) and presence of (A) anti-CD44 antibody $(50 \mu \mathrm{g} / \mathrm{mL})$ pretreated for I $\mathrm{h}$ and $(\mathbf{B})$ dynamin inhibitor I with $0.2 \%$ DMSO in the solution (DI; dynasore, $80 \mu \mathrm{M})$ pretreated for I h.

Notes: Untreated group represents the cell cultured without Q-complexes. LPD: a cationic liposome, multifunctional peptide, and DNA at optimized ratios; HLPD: $\mathrm{H}$ represents hyaluronic acid, $\mathrm{L}$ represents cationic liposome that was composed of DOTAP/DOPE at a I:I weight ratio, $P$ represents peptide $\left(P_{a}-P_{d}\right.$ refers to the different peptide used), and $D$ represents DNA. The means of four replicates \pm standard deviation are: $n s, P>0.05 ; *, P>0.05 ; * *, P>0.01 ;$ and $* * *, P>0.00 I$.

Abbreviations: FITC, fluorescein isothiocyanate; HA, hyaluronic acid; DOTAP, I,2-dioleoyl-3-trimethylammonium-propane; DOPE, I,2-dioleoylsn-glycero-3-phosphatidylethanolamine; ns, not significant.

were hypothesized to achieve intracellular delivery through multifunctional peptide completely wrapping nucleic acids and strongly penetrating specific tumor cell lines. Consequently, we employed DOPE lipid component to disrupt the endosomal membrane, in addition to the negatively charged HA coating at the surface of ternary complexes to shield the positive surface charges and highly effective targeting tumor. The experimental results showed that the nanocomplexes containing different peptide components possessed similar sizes (Figure 1), and the zeta potential of $\mathrm{LP}_{\mathrm{c}} \mathrm{D}$ was negative at approximately $-19 \mathrm{mV}$; other LPD formulations had positive surface charge. The electrophoretic mobility results (Figure 2) indicated that LP $\mathrm{D}_{\mathrm{c}}$ and $\mathrm{HLP}_{\mathrm{c}} \mathrm{D}$ could not tightly wrap DNA. In contrast to other spherical nanoparticles, the morphology and structure of $\mathrm{LP}_{\mathrm{c}} \mathrm{D}$ and $\mathrm{HLP}_{\mathrm{c}} \mathrm{D}$ obviously changed to crystal lamellas, which perhaps implied the reason why the samples containing $\mathrm{P}_{\mathrm{c}}$ had bare DNA transfection efficiency. The circular dichroism result (Figure 4) further demonstrated that folding or conformational changes in $\mathrm{P}_{\mathrm{c}}$ integrated into $\mathrm{LP}_{\mathrm{c}} \mathrm{D}$ and $\mathrm{HLP}_{\mathrm{c}} \mathrm{D}$ caused the minimal cell uptake and almost failure in transport DNA ability of the delivery system. Taking the results of cell uptake (Figure 5) and transfection efficiencies (Figures 6 and 7) into account, we thought that the reason why complexes with $\mathrm{P}_{c}$ showed low efficiency might be that undesirable formation could not be changed immediately in the transport process as $G A$ is a noncleavable spacer. Additionally, when $R V R R$ instead of $G A$ was used as a spacer in $\mathrm{P}_{\mathrm{d}}$, the morphologies of nanocomplexes were still spherical, and the conformational change of $\mathrm{P}_{d}$ occurred in $\mathrm{HLP}_{d} \mathrm{D}$ but not in $\mathrm{LP}_{\mathrm{d}} \mathrm{D}$. Therefore, different inserted spacer elements of peptides could result in different morphologies and transfection efficiencies of LPD and HLPD formations. The enhanced cellular uptake and transfection efficiency of $\mathrm{LP}_{\mathrm{d}} \mathrm{D}$ and $\mathrm{HLP}_{\mathrm{d}} \mathrm{D}$ demonstrated that the negative effect of $R V R R$ on the intracellular delivery efficiency was lower than that of $G A$. Thus, the crystal morphologies of complexes and some conformational changes in multifunctional peptides might shield their penetrating function or weaken their penetrating ability. However, when the multifunctional peptide was formed without spacer, the strong cell-penetrating function of KRPTMRFRYTWNPMK and tightly wrapping nucleic acid capability of $\mathrm{R}_{16}$ could be fully manifested in $\mathrm{LP}_{\mathrm{a}} \mathrm{D}$ and $\mathrm{HLP}_{\mathrm{a}} \mathrm{D}$. Moreover, the $\mathrm{LP}_{\mathrm{a}} \mathrm{D}$ and $\mathrm{HLP}_{\mathrm{a}} \mathrm{D}$ formulations showed unified spherical morphology, and the $\mathrm{P}_{\mathrm{a}}$ in the ternary and Q-complexes maintained unchangeable configuration. The function of HA was mainly in shielding the positive charge and pushing the nanoparticles to bind to the tumor cells. $\mathrm{LP}_{\mathrm{a}} \mathrm{D}$ and $\mathrm{HLP}_{\mathrm{a}} \mathrm{D}$ transport DNA mainly through dynamin-dependent and CD44-mediated independent pathways (Figure 6), which is completely different from the traditional drug delivery system utilizing HA for both targeting CD44 receptor and entering the cell through CD44-mediated pathway. ${ }^{15,22,23}$

\section{Conclusion}

We rationally designed a stable delivery platform for in vivo nucleic acid delivery based on modular design, which integrates a specific tumor lineage-homing cell-penetrating peptide and gene-condensing peptide into a multifunctional peptide that can both envelope nucleic acids and penetrate the tumor cell membrane. This study has proven that spacers in the peptide could decrease and prevent the intracellular 
transfection efficiency through reversing the complexes morphology from sphere to crystal lamellae and changing the peptide configuration. These findings will be important in understanding the formulation of Q-complexes and beneficial in designing an improved gene delivery system in the future.

\section{Acknowledgments}

This work was supported by the National Natural Science Foundation of China (Grant No 30901881 and 31470587) and Engineering and Medical Cooperation Projects of Shanghai Jiao Tong University (No YG2013MS42 and YG2014QN04).

\section{Disclosure}

The authors report no conflicts of interest in this work.

\section{References}

1. Nguyen J, Szoka FC. Nucleic acid delivery: the missing pieces of the puzzle? Acc Chem Res. 2012;45(7):1153-1162.

2. Ibraheem D, Elaissari A, Fessi H. Gene therapy and DNA delivery systems. Int J Pharm. 2014;459(1-2):70-83.

3. Yang ZR, Wang HF, Zhao J, et al. Recent developments in the use of adenoviruses and immunotoxins in cancer gene therapy. Cancer Gene Ther. 2007;14(7):599-615.

4. Guo X, Huang L. Recent advances in nonviral vectors for gene delivery. Acc Chem Res. 2012;45(7):971-979.

5. Yin H, Kanasty RL, Eltoukhy AA, Vegas AJ, Dorkin JR, Anderson DG. Non-viral vectors for gene-based therapy. Nat Rev Genet. 2014;15(8): $541-555$.

6. Morris VB, Labhasetwar V. Arginine-rich polyplexes for gene delivery to neuronal cells. Biomaterials. 2015;60:151-160.

7. Lu S, Morris VB, Labhasetwar V. Codelivery of DNA and siRNA via arginine-rich PEI-based polyplexes. Mol Pharm. 2015;12(2):621-629.

8. Khargharia S, Kizzire K, Ericson MD, Baumhover NJ, Rice KG. PEG length and chemical linkage controls polyacridine peptide DNA polyplex pharmacokinetics, biodistribution, metabolic stability and in vivo gene expression. J Control Release. 2013;170(3):325-333.

9. Olins DE, Olins AL, Von Hippel PH. Model nucleoprotein complexes: studies on the interaction of cationic homopolypeptides with DNA. J Mol Biol. 1967;24(2):157-176.
10. Marimani MD, Ely A, Buff MC, et al. Inhibition of replication of hepatitis $\mathrm{B}$ virus in transgenic mice following administration of hepatotropic lipoplexes containing guanidinopropyl-modified siRNAs. J Control Release. 2015;209:198-206.

11. Sitharaman B, Zakharian TY, Saraf A, et al. Water-soluble fullerene (C60) derivatives as nonviral gene-delivery vectors. Mol Pharm. 2008; 5(4):567-578.

12. Kozielski KL, Rui Y, Green JJ. Non-viral nucleic acid containing nanoparticles as cancer therapeutics. Expert Opin Drug Deliv. 2016; 13(10):1475-1487.

13. Kondo E, Saito K, Tashiro Y, et al. Tumour lineage-homing cellpenetrating peptides as anticancer molecular delivery systems. Nat Commun. 2012;3:951.

14. Stern R. Hyaluronan metabolism: a major paradox in cancer biology. Pathol Biol. 2005;53(7):372-382.

15. Yamada $\mathrm{Y}$, Hashida M, Harashima H. Hyaluronic acid controls the uptake pathway and intracellular trafficking of an octaarginine-modified gene vector in CD44 positive- and CD44 negative-cells. Biomaterials. 2015;52:189-198.

16. Mustapa MF, Bell PC, Hurley CA, et al. Biophysical characterization of an integrin-targeted lipopolyplex gene delivery vector. Biochemistry. 2007;46(45):12930-12944.

17. Munye MM, Ravi J, Tagalakis AD, McCarthy D, Ryadnov MG, Hart SL. Role of liposome and peptide in the synergistic enhancement of transfection with a lipopolyplex vector. Sci Rep. 2015;5:9292.

18. Hua Q, Knudson CB, Knudson W. Internalization of hyaluronan by chondrocytes occurs via receptor-mediated endocytosis. J Cell Sci. 1993; 106(pt 1):365-375.

19. Du Z, Munye MM, Tagalakis AD, Manunta MD, Hart SL. The role of the helper lipid on the DNA transfection efficiency of lipopolyplex formulations. Sci Rep. 2014;4:7107.

20. Marina-Garcia N, Franchi L, Kim YG, et al. Clathrin- and dynamindependent endocytic pathway regulates muramyl dipeptide internalization and NOD2 activation. J Immunol. 2009;182(7):4321-4327.

21. Nakase I, Tadokoro A, Kawabata N, et al. Interaction of arginine-rich peptides with membrane-associated proteoglycans is crucial for induction of actin organization and macropinocytosis. Biochemistry. 2007;46(2): $492-501$.

22. Chono S, Li SD, Conwell CC, Huang L. An efficient and low immunostimulatory nanoparticle formulation for systemic siRNA delivery to the tumor. J Control Release. 2008;131(1):64-69.

23. He Y, Cheng G, Xie L, Nie Y, He B, Gu Z. Polyethyleneimine/DNA polyplexes with reduction-sensitive hyaluronic acid derivatives shielding for targeted gene delivery. Biomaterials. 2013;34(4):1235-1245. 


\section{Supplementary materials}
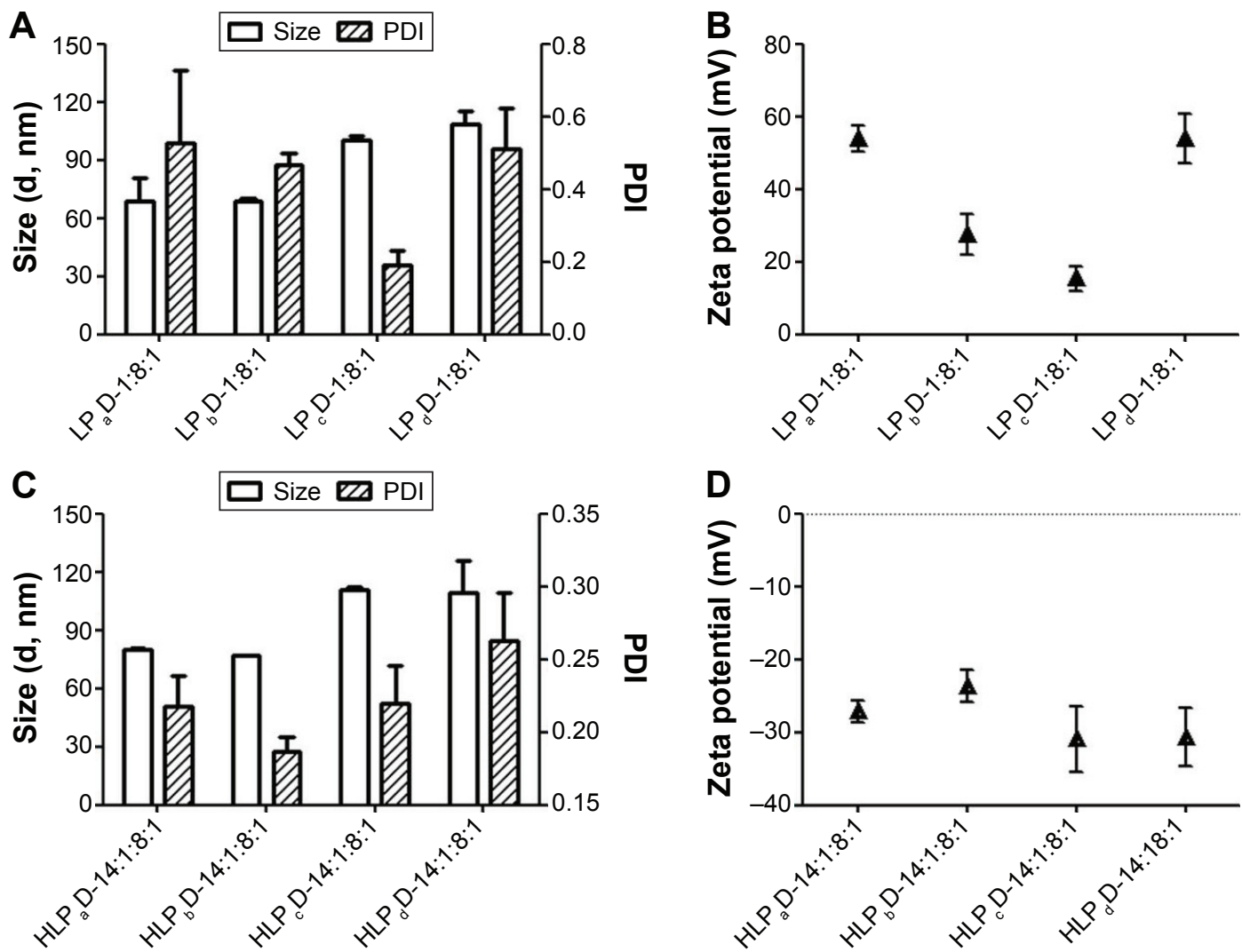

Figure SI (A-D) The results of hydrodynamic size and zeta potential measurements of ternary complexes and Q-complexes wrapping pGI3 plasmid.

Notes: The data is the weight ratio of each component in Q-complexes. For example, "H:L:P:D-I4:I:8:I" refers to hyaluronic acid, cationic liposome, $\mathrm{P}_{\mathrm{a}}$ and DNA at I4:I:8: I weight ratios. LPD: a cationic liposome, multifunctional peptide, and DNA at optimized ratios; HLPD: $H$ represents hyaluronic acid, $L$ represents cationic liposome that was composed of DOTAP/DOPE at a I:I weight ratio, $\mathrm{P}$ represents peptide ( $\mathrm{P}-\mathrm{P}$ refers to the different peptide used), and $\mathrm{D}$ represents $\mathrm{DNA}$.

Abbreviation: PDI, polydispersity index.

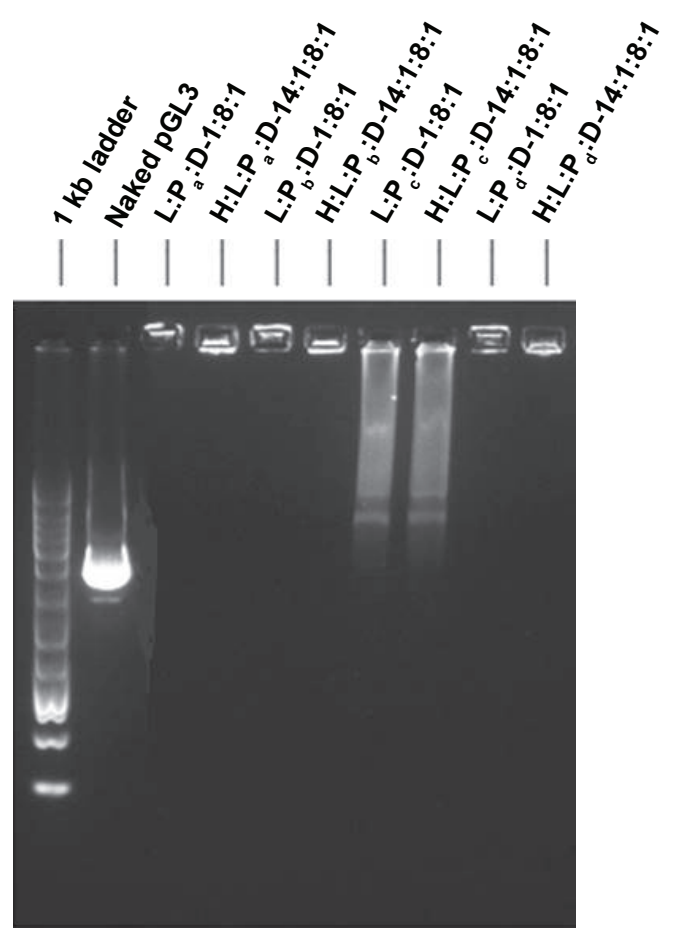

Figure S2 Electrophoretic mobility in I\% agarose gel for ternary complexes and Q-complexes wrapping PGL3 plasmid. 
International Journal of Nanomedicine

Dovepress

\section{Publish your work in this journal}

The International Journal of Nanomedicine is an international, peerreviewed journal focusing on the application of nanotechnology in diagnostics, therapeutics, and drug delivery systems throughout the biomedical field. This journal is indexed on PubMed Central, MedLine, CAS, SciSearch ${ }^{\circledR}$, Current Contents ${ }^{\circledR} /$ Clinical Medicine,
Journal Citation Reports/Science Edition, EMBase, Scopus and the Elsevier Bibliographic databases. The manuscript management system is completely online and includes a very quick and fair peer-review system, which is all easy to use. Visit http://www.dovepress.com/ testimonials.php to read real quotes from published authors.

Submit your manuscript here: http://www.dovepress.com/international-journal-of-nanomedicine-journal 